\title{
Role of Ethylene in Opening and Senescence of Gladiolus sp. Flowers
}

\author{
Margrethe Serek ${ }^{1}$, Rodney B. Jones ${ }^{2}$, and Michael S. Reid \\ Department of Environmental Horticulture, University of California, Davis, CA 95616
}

Additional index words. Carbohydrate, flower opening, flower senescence, flower spike, silver thiosulfate, sucrose

\begin{abstract}
The opening and senescence of gladiolus (Gladiolus $s p$.) florets was accompanied by climacteric or nonclimacteric patterns of respiration and ethylene production, depending on variety, and whether data were expressed on a fresh-weight or floret basis. A climacteric pattern of ethylene production by the youngest buds on the spike (which never opened) was stimulated by cool storage, and was not affected by holding the spikes in a preservative solution containing sucrose. Ethylene treatment had no effect on senescence of the florets of any of the cultivars tested. Pulse treatment of the spikes with silver thiosulfate (STS) improved floret opening but not the life of individual florets. Sucrose and STS had similar but not synergistic effects on floret opening, suggesting that STS improves flower opening in gladiolus by overcoming the effects of carbohydrate depletion.
\end{abstract}

Gladiolus are prized by florists for their showy flower spikes, and by growers for their relative ease of production. Like other flowers with spike inflorescences, gladiolus are normally harvested with relatively few open florets, and the life of the flower is a function both of the life of individual florets, and of the postharvest expansion and opening of the buds remaining on the spike. Ideally, many of the florets on the spike should open before the senescence of the bottom florets. Because the dead florets are unattractive, senescence of the bottom florets marks the end of the flower spike's commercial display life. The typical life of these florets on a spike placed in water is 4 to 6 days (Marousky, 1968; Mayak et al., 1973). Modest increases in the life of gladiolus flowers have been gained by pulsing with sucrose, or using vase preservatives containing sucrose (Marousky, 1971).

Little has been done to examine the physiological basis of senescence in gladiolus, and no work has been reported on the physiology of individual florets. This is surprising, since gladiolus flower spikes offer an interesting model system for studies of flower senescence. Individual florets provide a graded series of stages of development and senescence in an identical genetic and environmental background. Many studies have examined the possible role of ethylene in gladiolus senescence. Woltering and van Doorn (1988) reported that treatment with ethylene ( $3 \mu \mathrm{l} \cdot$ liter $\left.{ }^{1}\right)$ for $24 \mathrm{~h}$ revealed little to no sensitivity as indicated by slight acceleration of petal wilting in only some cultivars. Pulse treatments with the silver thiosulfate anionic complex (STS) have likewise provided little (Farhoomand, 1978) or no (Mor et al., 1981) benefit. In contrast, Merodio and de la Plaza (1989) reported that ethylene removal during storage improved the subsequent

Received for publication 1 Nov. 1993. Accepted for publication 23 Feb. 1994. The experiment was supported by a grant from the Danish Agricultural and Veterinary Research Council (grant no. 13-4549) and supplementary grants from the Foundation of Hofmansgave, the Foundation of Ib Henriksen and the Carlsberg Foundation (MS), and the Australian Department of Industry, Technology and Commerce Bilateral Science Exchange Program (RBJ). We acknowledge the assistance of Carol Adams, Gail Nishimoto, and the late F. Jackson Hills with data analysis, Linda Dodge and Mercedes Fernandez Sanchez for technical assistance, and Suyeyasu Wholesale Florists and Glad-Away Gardens for generous donations of gladiolus flowers. The cost of publishing this paper was defrayed in part by the payment of page charges. Under postal regulations, this paper therefore must be hereby marked advertisement solely to indicate this fact.

${ }^{1}$ Permanent address: The Royal Veterinary and Agricultural University, Department of Agricultural Sciences, Section for Horticulture, Rolighedsvej 23, 1958 Frederiksberg C., Denmark. To whom reprint requests should be addressed. ${ }^{2}$ Permanent address: Institute of Plant Sciences, Knoxfield, P.O. Box 174 Ferntree Gully, Victoria 3156, Australia. vase life of 'pink' and 'white' gladiolus cultivars. Ethylene removal also resulted in reduced water and color loss, and improved stem 'rigidity'. Murali and Reddy (1993) used a range of metal salts (in combination with sucrose) and found a positive correlation between the effects of their treatments on ethylene production and vase life of the flower spikes. Thus, the role of ethylene in senescence of gladiolus petals and the life of the flower spikes is unclear.

In this study, we examined the role of ethylene in floret senescence of gladiolus flowers by determining ethylene production and respiration of individual florets during development and senescence, and by exploring the effects of exogenous ethylene, STS, and sucrose treatments on opening and senescence of florets in a range of commercial cultivars.

\section{Materials and Methods}

Plant materials. Gladiolus flowers, harvested at normal commercial maturity in a local nursery (Fremont, Calif.), were shipped under ambient conditions to Univ. of California, Davis, (within 24 $\mathrm{h}$ of harvest), and placed in a cool room (2C) for up to $24 \mathrm{~h}$ before use in experiments. Before physiological experiments, spikes were normally recut, placed in deionized (DI) water in a standard vase-life environment [20C, 50\% to $60 \%$ relative humidity (RH), $15 \mu \mathrm{mol} \cdot \mathrm{m}^{-2} \cdot \mathrm{s}^{-1}$ for $12 \mathrm{~h} /$ day], and allowed to equilibrate for 2 to 3 days. Flower longevity was determined as the time from opening to wilting of the third floret from the bottom of each spike.

Measurement of ethylene production and respiration. Florets were excised from spikes of a range of gladiolus cultivars at six stages of development (Fig. 1). Excised florets were placed with their bases in a $30-\mathrm{ml}$ vial containing DI water, inside 0.24 -liter glass jars flushed with ethylene-free air, and were then sealed with a metal lid fitted with a serum cap, and held for $1 \mathrm{~h}$ at 20C. A 3-ml aliquot of the air in the jar was then withdrawn for measurement of ethylene, using a gas chromatograph fitted with a flame-ionization detector (Carle AGC 111, Anaheim, Calif. and HNU PI-51, Newton, Mass.). An additional 1-ml aliquot was withdrawn for analysis of $\mathrm{CO}_{2}$ content, using an Infrared Gas Analyzer (Analytical Development Co., Hoddesdon, U.K.).

Patterns of ethylene production of the ten youngest florets on the spike were determined by dissecting the buds and placing their bases in a droplet of water inside a $25-\mathrm{ml}$ vial sealed with a serum cap. Ethylene production was determined as described above.

Effect of ethylene on flower opening and senescence. Untreated spikes were shortened to $30 \mathrm{~cm}$ (by removal of most of the basal 


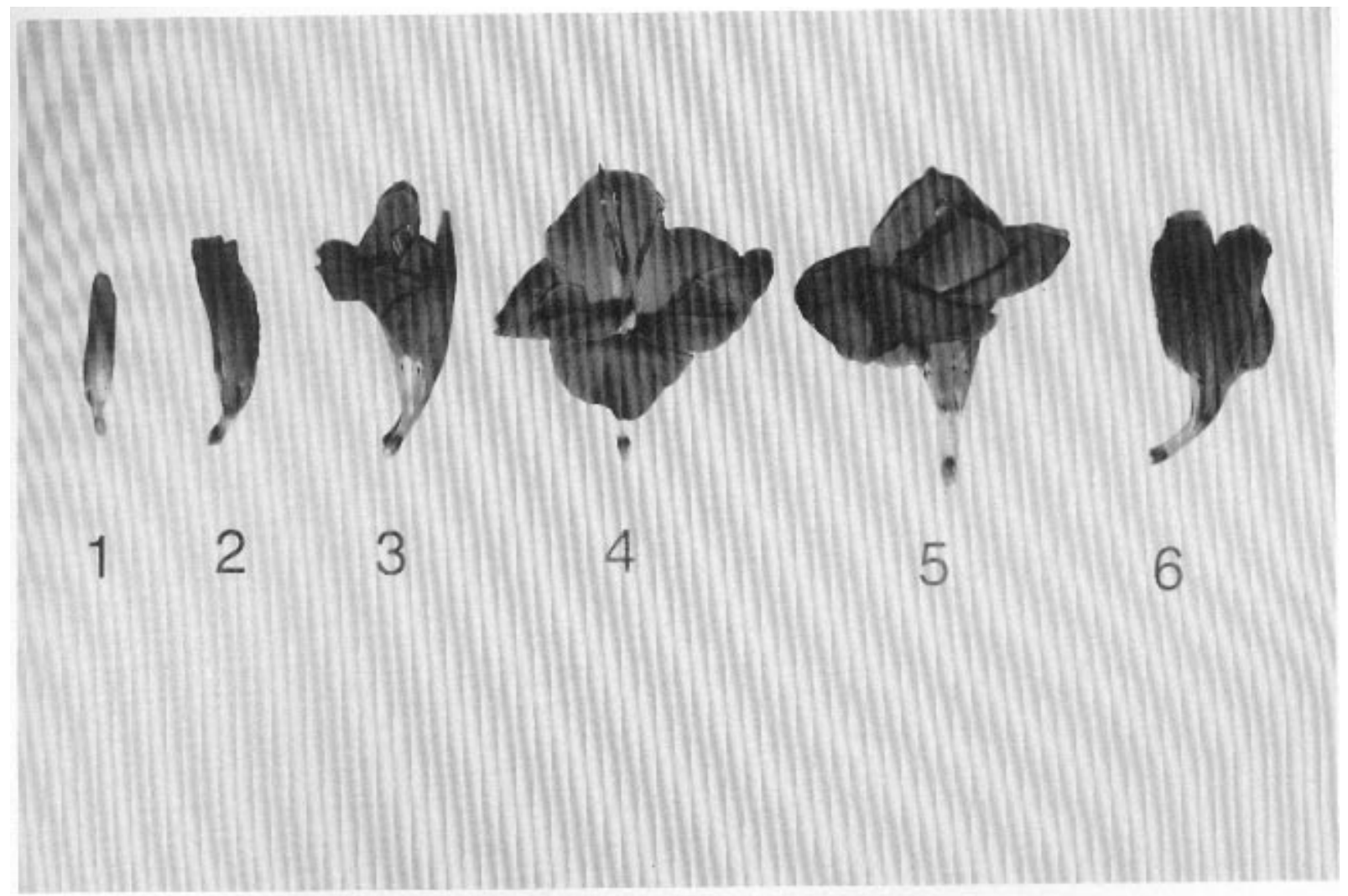

Fig. 1. Stages of development in gladiolus florets. (1.) Tight bud. (2.) Bud. (3.) Half-open. (4.) Fully open. (5.) Incipient senescence (indicated by water soaking or wilting of petal margins). (6.) Senescent.

stem, and most unopened buds) and were then placed in DI water in large (40-liter) glass chambers ventilated $\left(40\right.$ liters $\left.\cdot \mathrm{h}^{-1}\right)$ with air containing $0,0.07,0.4$, or $1 \mu \mathrm{l} \cdot$ liter $^{-1}$ ethylene. The effects of ethylene on flower senescence were evaluated daily.

Effects of STS and sucrose. Newly harvested spikes were pulsed with STS $\left(1 \mathrm{~mm} \mathrm{Ag}^{+}\right)$for $2 \mathrm{~h}$ at room temperature, and were then placed in the vase-life room in DI water, or in 1\% sucrose (both solutions containing $250 \mathrm{mg}$.liter ${ }^{-1}$ 8-hydroxyquinoline citrate (HQC). Spike opening was determined daily, and at 3 days the newly opened floret fourth from the bottom of each spike was removed and weighed.

Statistics. Statistical procedures were performed using the PCSAS software package. General linear models two-factor analysis of variance (ANOVA) with replications in cells, orthogonal comparisons, or Student's $t$ test were used to examine differences between means.

\section{Results}

Variation in cultivar longevity. The life of different gladiolus cultivars (measured as days from opening to wilting of the third floret from the bottom of each spike) varied by more than 50\% (Table 1).

Respiration. The pattern of respiration of gladiolus florets at various developmental stages was broadly similar for different cultivars (Fig. 2 a and b). Expressed on a per-floret basis (Fig. 2a), respiration tended to be low in tight buds and in senescent florets, with a broad peak (especially pronounced in 'Nancy' and 'New Rose') during opening and development. In general, respiration was highest in incipiently senescent floret (stage 5). On a fresh-weight basis floret respiration showed a climacteric-like pattern, falling during floret development, then rising during floret senescence.

Ethylene production. The developmental pattern of ethylene
Table 1.Longevity of gladiolus flowers in relation to STS treatment $(1 \mathrm{mM}$ $\left.\mathrm{Ag}^{+}\right)$. Newly harvested spikes were pulsed with DI water or STS for 2 $\mathrm{h}$, and then placed in DI water under controlled conditions for assessment of flower life, days from opening to wilting of the third floret.

Flower longevity

(days)

Cultivars

St. Patrick

4.3

Captain Busch

5.2

Fond Memory

3.3

Blue Mountain

4.8

New Rose

4.7

Nancy

Treatments

DI

STS

Cultivar

$* * *$

Treatment

GLM two-factor analysis

Cultivar $\times$ treatment

NS

NS

$\overline{\mathrm{Ns}, * * *}$ Nonsignificant or significant at $P=0.001$, respectively.

production varied with cultivar (Fig. 3a). In 'New Rose' and 'Nancy', it followed a climacteric-like pattern, high before the onset of petal wilting, and falling substantially with petal wilting. In other cultivars the climacteric pattern was less obvious. On a fresh-weight basis, ethylene production was found to be highest in tight buds (Fig. 3b), and it rose during senescence. Ethylene production of senescing florets of most cultivars was about $2 \mu \mathrm{l} \cdot \mathrm{kg}^{-1} \cdot \mathrm{h}^{-1}$.

Effects of cool storage and sucrose on ethylene production of 

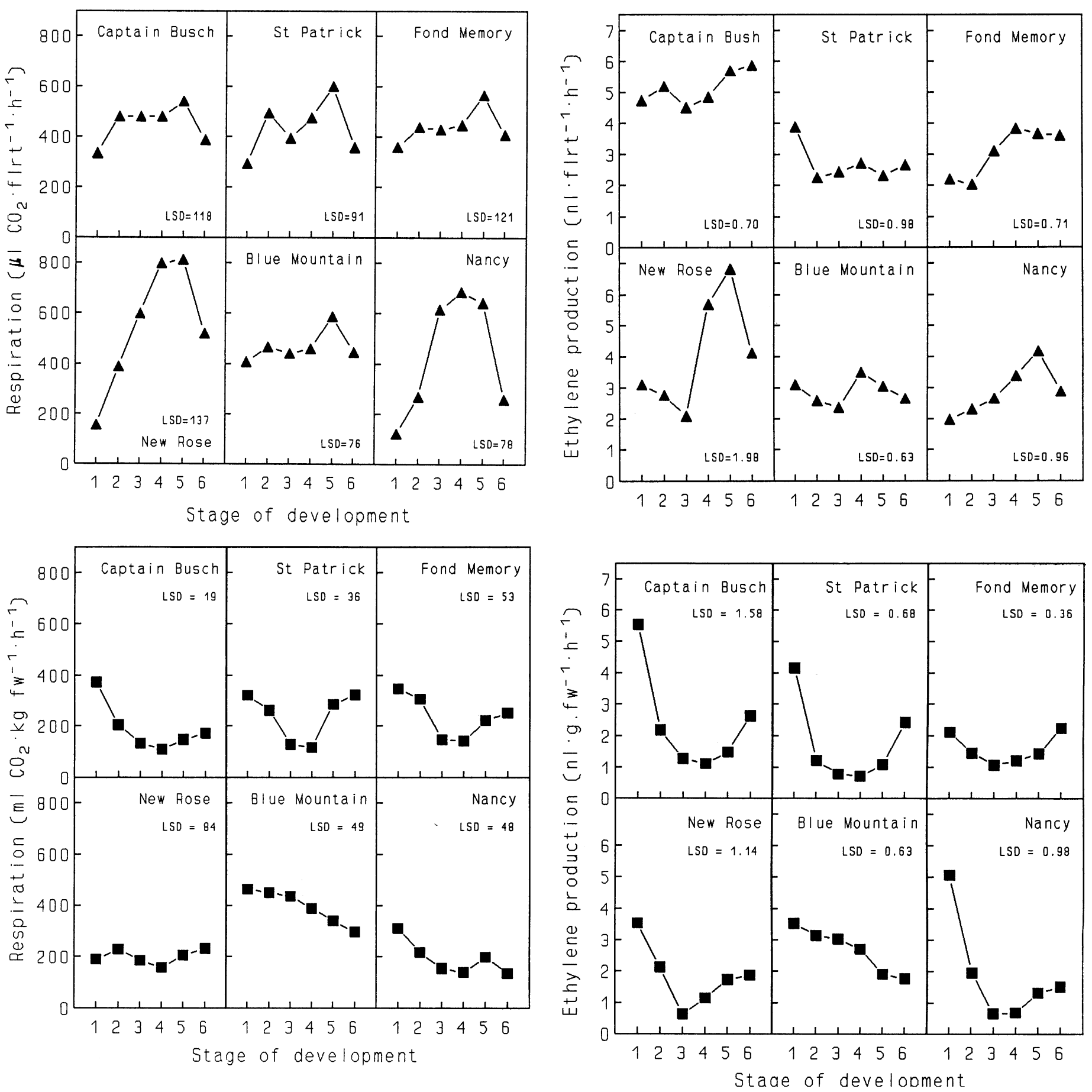

Fig. 2. Respiration expressed as $\mathrm{CO}_{2} /$ floret $\left(\mu 1 \cdot \mathrm{h}^{-1}\right)$ (top) or expressed as $\mathrm{ml} \mathrm{CO}_{2} /$ $\mathrm{kg}$ perh (bottom) in six gladiolus cultivars. Respiration was measured at the six stages of development shown in Fig. 1.

developing buds. Ethylene production of the 10 terminal buds of freshly harvested spikes of 'New Rose' was very low (Fig. 4a). After 1 day in the vase, ethylene production had increased dramatically in the youngest buds; production fell with increasing bud age and time in the vase (Fig. 4a). Ethylene production in the terminal buds of flower spikes that had been cool-stored (2C, 3 days) followed a similar pattern, but was twice as high as that of buds from freshly harvested spikes (Fig. 4b). Holding the spikes in a vase solution containing $1 \%$ sucrose had no consistent effect on patterns of ethylene production by the terminal buds (data not shown).

Effects of ethylene. Senescence of florets was not affected by the

Fig. 3. Ethylene production per floret $\left(\mathrm{nl} \cdot \mathrm{h}^{-1}\right)$ (top) or expressed as $\mathrm{nl} \cdot \mathrm{g}^{-1} \cdot \mathrm{h}^{-1}$ (bottom) in six gladiolus cultivars. Ethylene production was measured at the six stages of development shown in Fig. 1.

continuous presence of ethylene at $0,0.07,0.1,0.4$, or $1 \mu \mathrm{l} \cdot$ liter $^{-1}$ in any of the tested cultivars (data not shown).

Effects of STS and sucrose. Pulse pretreatment of flower spikes with STS had no significant effect on longevity of individual florets (Table 1), but did have a significant effect on spike opening (Tables 2 and 3), with an average $10 \%$ increase in the number of florets opening on STS-treated spikes. The presence of sucrose in the vase solution increased the number of florets opening very similarly to STS-treated spikes (Table 2). Addition of sucrose to the STS pulse had no significant additional effect on spike opening 

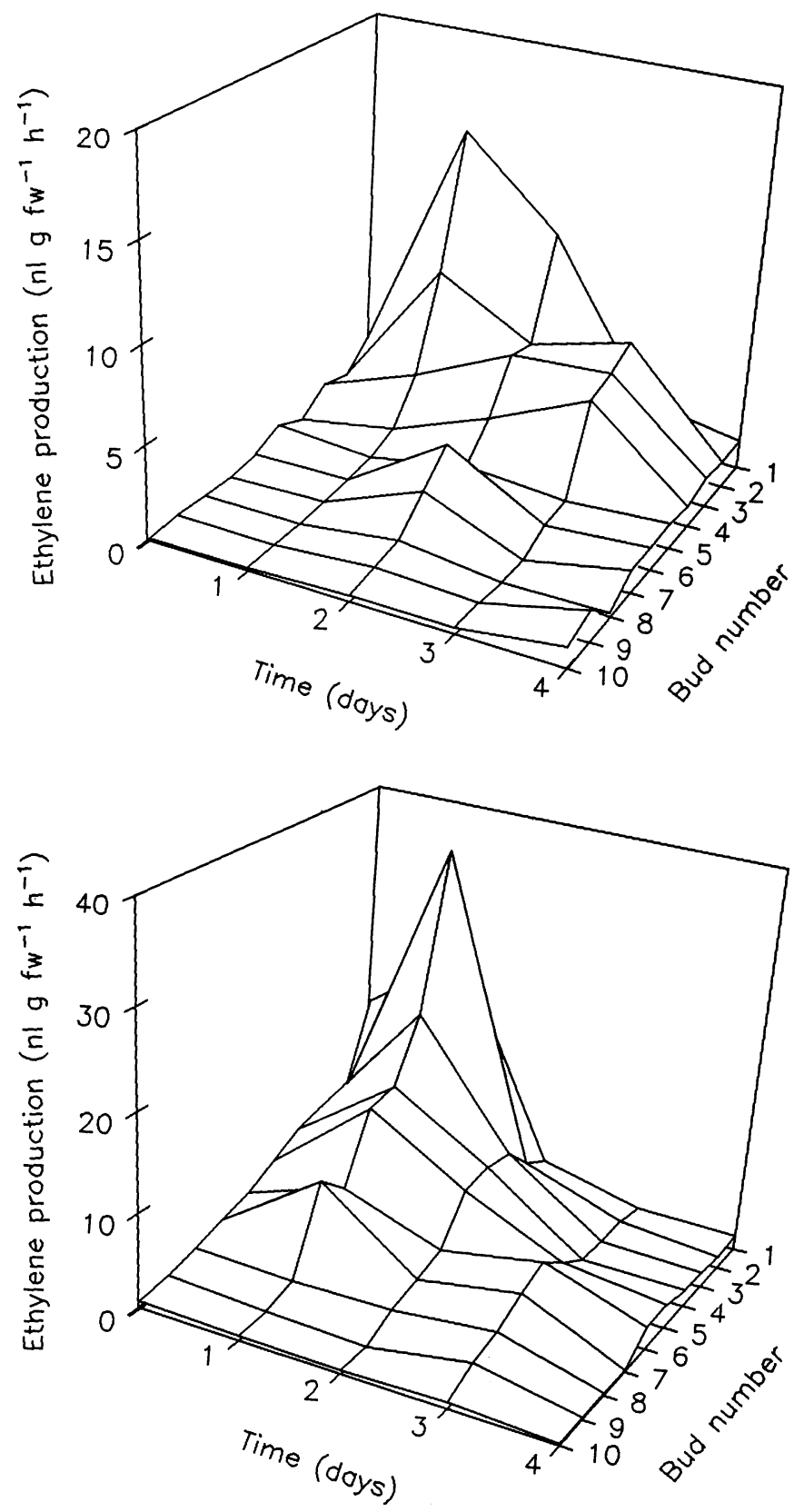

Fig. 4. Ethylene production (expressed in $\mathrm{nl} \cdot \mathrm{g}^{-1} \cdot \mathrm{h}^{-1}$ ) in the 10 terminals buds (smallest bud is numbered 1) of spikes of gladiolus cultivar New Rose. (Top) Freshly harvested spikes $(\mathrm{LSD}=0.6)$. (Bottom) cool-stored $(2 \mathrm{C}, 3$ days $)$ spikes $(\mathrm{LSD}=0.8)$.

(Tables 2 and 3), but did further increase the fresh weight of individual florets of some cultivars (Table 4). The effects of STS and sucrose were similar, not additive (Tables 2 and 3 ).

\section{Discussion}

Our data suggest that gladiolus, like many other geophytes (Reid and Wu, 1991), is an ethylene-insensitive flower. Despite the modest climacteric-like peak in ethylene production in some cultivars, and the broad peak of respiration that accompanies spike opening and senescence, we found the florets to be insensitive to exogenous ethylene (data not presented). The different vase life of the individual cultivars that we studied showed no consistent relationship to the pattern of ethylene production and respiration.
Table 2. Effect of sucrose and STS on spike opening and fresh weight of individual florets of gladiolus 'New Rose'. Newly harvested spikes were pulsed with DI water or STS (1 mM) for $2 \mathrm{~h}$, and then transferred to DI or $1 \%$ sucrose (both containing $250 \mathrm{mg} \cdot \operatorname{liter}^{-1} \mathrm{HQC}$ ) and held under controlled conditions for assessment of spike opening. The floret fourth from the bottom of each spike was excised after 3 days and weighed.

\begin{tabular}{lcc}
\hline & Spike opening $(\%)$ & Fresh weight $(\mathrm{g})$ \\
\hline DI & 57.9 & 5.68 \\
STS & 65.0 & 6.65 \\
Sucrose & 65.5 & 6.81 \\
Sucrose + STS & 66.4 & 6.93 \\
& Contrast & \\
DI vs. others & $* * *$ & $* *$ \\
Sucrose vs. STS & NS & NS \\
Sucrose vs. STS + sucrose & NS & NS \\
STS vs. STS + sucrose & NS & NS \\
\hline NS,**,***Nonsignificant or significant at $P=0.01$ or 0.001, respectively.
\end{tabular}

$\overline{\mathrm{NS},{ }^{, * *},{ }^{* * *} \text { Nonsignificant or significant at } P=0.01 \text { or } 0.001 \text {, respectively. }}$

Table 3. Opening of spikes of a range of gladiolus cultivars in relation to treatment with STS, and STS + sucrose. Newly harvested spikes were pulsed with DI water or STS for $2 \mathrm{~h}$, and were then placed in DI water (DI and STS-pulsed spikes) or in 1\% sucrose (STS-pulsed spikes). Both solutions contained $250 \mathrm{mg} \cdot \mathrm{liter}^{-1} \mathrm{HQC}$. Spike opening was determined at the end of vase life.

\begin{tabular}{|c|c|}
\hline & $\begin{array}{c}\text { Spike opening } \\
(\%)\end{array}$ \\
\hline \multicolumn{2}{|c|}{ Cultivar } \\
\hline Blue Mountains & 89.8 \\
\hline Captain Busch & 90.7 \\
\hline Goldfield & 80.0 \\
\hline Ice Cap & 75.2 \\
\hline New Rose & 65.2 \\
\hline Prima Classic & 87.8 \\
\hline St. Patrick & 83.4 \\
\hline Violetta & 67.0 \\
\hline \multicolumn{2}{|c|}{ Treatment } \\
\hline DI & 73.9 \\
\hline STS & 81.8 \\
\hline STS + sucrose & 82.4 \\
\hline \multicolumn{2}{|c|}{ GLM two-factor analysis and contrast } \\
\hline Cultivar & $* * *$ \\
\hline Treatment & $* *$ \\
\hline Cultivar $\times$ treatment & NS \\
\hline DI vs. others & $* *$ \\
\hline STS vs. STS + sucrose & NS \\
\hline
\end{tabular}

For example, the patterns of ethylene production and respiration of 'Fond Memory', with the shortest vase life (3.3 days), and 'Captain Busch', the longest-lived (5.2 days), were quite similar. The changes in floret fresh weight that accompany opening and senescence explain the marked differences in patterns of respiration and ethylene production expressed on 'per floret' and 'per gram freshweight basis' (Figs. 2 and 3). Ethylene production in senescing florets was quite low $\left(2 \mu \mathrm{l} \cdot \mathrm{kg}^{-1} \cdot \mathrm{h}^{-1}\right)$ compared to that of senescing carnations $\left(200 \mu 1 \cdot \mathrm{kg}^{-1} \cdot \mathrm{h}^{-1}\right)$ (Nichols et al., 1983).

Woltering and van Doorn (1988) concluded, based on the effects of a 24-h exposure to $3 \mu \mathrm{l} \cdot$ liter $^{-1}$ ethylene (higher than our highest treatment concentration), that gladiolus were slightly sensitive to ethylene. They noted some acceleration of petal 
wilting and bud drying. Although we treated the spikes continuously with $1 \mu l \cdot 1^{-1}$ ethylene, we found no significant effect of ethylene on floret senescence. The removal of smaller buds to fit the spikes to our treatment tanks may, however, have prevented us from observing possible effects of ethylene on bud drying.

Treatment with STS had no significant effect on floret longevity, another indication that ethylene action is not involved in the senescence of gladiolus florets. It is unlikely that this is due to a failure of STS to reach the buds and florets; STS is highly mobile in many flower stems, and had a significant effect on spike opening (Tables 2 and 3). Murali and Reddy (1993) noted that a number of metal salts, including $\mathrm{CoCl}_{2}$, had a positive effect on spike longevity and opening of gladiolus. Since cobalt ion is an effective inhibitor of ethylene biosynthesis (Yeong-Biau and Yang, 1979), they concluded that the increased spike life was the result of reduced ethylene biosynthesis. This conclusion is, however, subject to other interpretations. The metal salts may have reduced bacterial growth and improved the uptake of sucrose, long known to be effective in extending spike life in gladiolus (Kofranek and Paul, 1975; Marousky, 1968). The high ethylene production rate that Murali and Reddy (1993) obtained (>100 times the amount we measured) may be an artifact of their measurement system, which confined the four bottom florets in a 0.5-liter container for $24 \mathrm{~h}$.

STS markedly improved the opening of gladiolus spikes in a mechanism that was apparently related to the effects of exogenous sucrose, since sucrose had no significant additional effect (Table 3 ). These data are consistent with the hypothesis that the smaller buds on gladiolus spikes may abort for lack of carbohydrate. In other species, such as freesia (Spikman, 1986) and lilies (van Meeteren et al., 1982), lack of carbohydrate has been shown to lead to increased ethylene biosynthesis and bud abortion. The bud drying reported by Woltering and van Doorn (1988), and the high ethylene production (per gram fresh weight) that we observed in young buds, especially after cold storage, are consistent with this suggestion. Curiously, supplying added carbohydrate did not consistently reduce ethylene production in very young buds. They may have insufficient sink strength to compete with the expanding buds for carbohydrate provided from the vase solution. Interestingly, while STS and sucrose had no additive effects on spike opening (Table 3), the fresh weight of florets treated with STS + sucrose was sometimes higher than that of florets treated with STS alone (Table 4). This is a further indication of the carbohydrate limitation in opening of gladiolus spikes of some cultivars. The most marked effect is for 'Captain Bush', which had the largest florets of the cultivars tested.

Merodio and de la Plaza (1989) found that removal of ethylene from the storage atmosphere improved the opening of gladiolus spikes, decreased water loss, and prevented changes in color and stem 'rigidity'. Our results make it difficult to understand how ethylene removal could explain all these effects, particularly since the maximum ethylene concentration reached in their control storage was $0.3 \mu 1 \cdot 1^{-1}$, and the storage temperature was low enough (2.5C) to greatly retard any effects of ethylene. Our data clearly indicate that, for the standard commercial cultivars we tested, ethylene is not a factor in floret senescence, and we conclude that gladiolus, like other geophytes in the Liliaceae (Reid, 1989), is an ethylene-insensitive flower. The control of senescence in gladiolus may be similar to that in daylily (Lay-Yee et al., 1992). Like gladiolus florets daylily flowers produce a transient peak of ethylene during senescence, but their wilting is not retarded by STS or hasted by application of exogenous ethylene. It will be interesting to further explore the senescence of gladiolus using daylily as a model.
Table 4. Effect of DI, STS, and STS + sucrose on fresh weight of individual florets of different gladiolus cultivars. Newly harvested spikes were pulsed with STS $\left(1 \mathrm{mM} \mathrm{Ag}^{+}\right)$or DI for $2 \mathrm{~h}$ at room temperature and were then placed in DI (both pretreatments) or sucrose (STS pretreatment). The fourth floret from the bottom of each spike was excised and weighed after 3 days in the vase.

\begin{tabular}{|c|c|c|}
\hline Cultivar & Treatment & Fresh wt (g) \\
\hline \multirow[t]{3}{*}{ St. Patrick } & DI & $2.9 a^{x}$ \\
\hline & STS & $3.5 \mathrm{~b}$ \\
\hline & STS + sucrose & $4.4 \mathrm{c}$ \\
\hline \multirow[t]{3}{*}{ New Rose } & DI & $4.6 \mathrm{a}$ \\
\hline & STS & $5.1 \mathrm{ab}$ \\
\hline & STS + sucrose & $5.3 \mathrm{~b}$ \\
\hline \multirow[t]{3}{*}{ Captain Busch } & DI & $4.9 \mathrm{a}$ \\
\hline & STS & $4.9 \mathrm{a}$ \\
\hline & STS + sucrose & $6.2 \mathrm{~b}$ \\
\hline \multirow[t]{3}{*}{ Blue Mountains } & DI & $3.3 \mathrm{a}$ \\
\hline & STS & $3.8 \mathrm{a}$ \\
\hline & STS + sucrose & $3.6 \mathrm{a}$ \\
\hline \multirow[t]{3}{*}{ Violetta } & DI & $3.1 \mathrm{a}$ \\
\hline & STS & $2.9 \mathrm{a}$ \\
\hline & STS + sucrose & $3.4 \mathrm{a}$ \\
\hline \multirow[t]{3}{*}{ Prima Classic } & DI & $2.9 \mathrm{a}$ \\
\hline & STS & $2.4 \mathrm{a}$ \\
\hline & STS + sucrose & $2.8 \mathrm{a}$ \\
\hline \multirow[t]{3}{*}{ Goldfield } & DI & $2.8 \mathrm{a}$ \\
\hline & STS & $3.4 \mathrm{ab}$ \\
\hline & STS + sucrose & $3.6 \mathrm{~b}$ \\
\hline \multirow[t]{3}{*}{ Ice Cap } & DI & $4.7 \mathrm{a}$ \\
\hline & STS & $4.1 \mathrm{a}$ \\
\hline & STS + sucrose & $5.5 \mathrm{~b}$ \\
\hline \multicolumn{3}{|c|}{ GLM two-factor analysis } \\
\hline \multicolumn{2}{|l|}{ Cultivar } & $* * *$ \\
\hline \multicolumn{2}{|c|}{ Treatment } & $* * *$ \\
\hline \multicolumn{2}{|c|}{ Cultivar $\times$ treatment } & ** \\
\hline
\end{tabular}

${ }^{\mathrm{x}}$ For each cultivar numbers followed by different letters in a column are statistically different at $P=0.05$ by $t$ test probability values for the hypotheses $\mathrm{H}_{\mathrm{o}}$ : $\operatorname{LSM}(\mathrm{i})=\operatorname{LSM}(\mathrm{j})$.

${ }^{* * * * * * *}$ Significant effects at $P=0.01$ or 0.001 , respectively.

\section{Literature Cited}

Farhoomand, M.B. 1978. Prolonging vase life of cut carnation and gladiolus by chemicals. HortScience 13:346. (Abstr.)

Kofranek, A.M. and J.L. Paul. 1975. The value of impregnating cut stems with high concentrations of silver nitrate. Acta Hort. 41:199-206.

Lay-Yee, M., A.D. Stead, and M.S. Reid. 1992. Flower senescence in daylily (Hemerocallis). Physiol. Plant. 86:308-314.

Marousky, F.J. 1968. Influence of 8-hydroxyquinoline citrate and sucrose on vase life and quality of cut gladiolus. Proc. Fla. State Hort. Soc. 81:415-419.

Marousky, F.J. 1971. Influence of 8-hydroxyquinoline citrate and sucrose on carbohydrate content of leaves and florets of cut gladiolus spikes. Acta Hort. 23:127-131.

Mayak, S., B. Bravdo, A. Gvilli, and A.H. Halevy. 1973. Improvement of opening of cut gladioli flowers by pretreatment with high sugar concentrations. Scientia Hort. 1:357-365.

van Meeteren, V. and M. de Proft. 1982. Inhibition of flower bud abscission and ethylene evolution by light and silver thiosulphate in lilium. Physiol. Plant. 56:236-240.

Merodio, C. and J.L. de la Plaza. 1989. Effects of post-harvest ethylene removal on cut flowering stems of gladiolus. Acta Hort. 246:327-333. Mor, Y., R.E. Hardenburg, A.M. Kofranek, and M.S. Reid. 1981. Effect of STS pretreatment on vase life of cut standard carnations, spray carnations and gladiolus, after a trans-continental truck shipment. Hort- 
Science 16:766-768.

Murali, T.P. and T.V. Reddy. 1993. Postharvest life of gladiolus as influenced by sucrose and metal salts. Acta Hort. 343:313-320.

Nichols, R., G. Bufler, Y. Mor, D.W. Fujino, and M.S. Reid. 1983. Changes in ethylene production and 1-aminocyclopropane-1-carboxylic acid content of pollinated carnation flowers. Plant Growth Regulat. 2:1-8.

Reid, M.S. 1989. The role of ethylene in flower senescence. Acta Hort. 261:157-169.

Reid, M.S. and M.J. Wu. 1991. Ethylene in flower development and senescence, p. 215-234. In: A.K. Mattoo and J.C. Suttle (eds.). The plant hormone ethylene. CRC Press, Boca Raton, Fla.

Spikman, G. 1986. The effect of water stress on ethylene production and ethylene sensitivity of Freesia inflorescences. Acta Hort. 181:135-140. Woltering, E.J. and W.G. Van Doorn. 1988. Role of ethylene in senescence of petals-morphological and taxonomical relationships. J. Expt. Bot. 39:1605-1606.

Yeong-Biau, Y., and S.F. Yang. 1979. Auxin-induced ethylene production and its inhibition by AVG and cobalt ion. Plant Physiol. 64:1074-1077. 